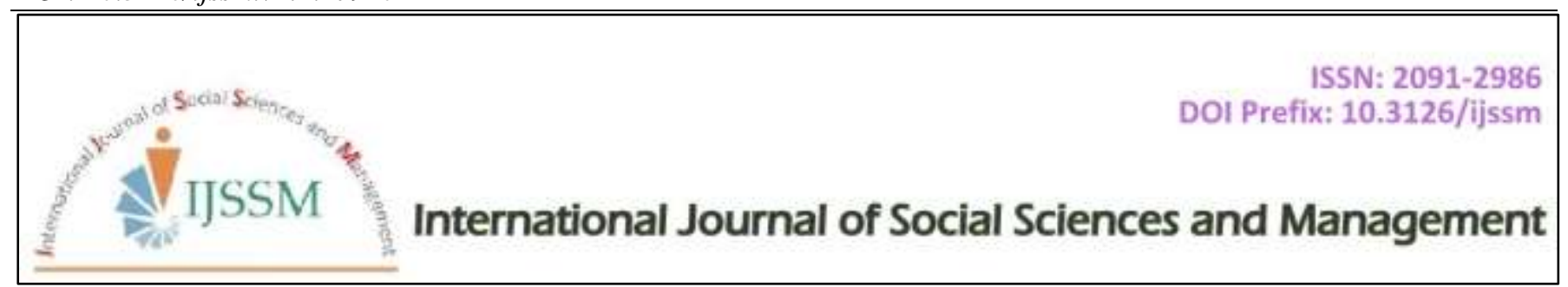

Research Article

\title{
Impact of Corporate Social Responsibility on Sustainable Competitive Advantage: A Case Study of Leading Noodle Companies in Nepal
}

\author{
Dinesh Raj Pant ${ }^{1 *}$ and Opas Piansoongnern ${ }^{2}$ \\ ${ }^{1}$ School of Management, Shinawatra University, Bangkok, Thailand \\ ${ }^{2}$ Assistant to the President for International Affairs, Shinawatra University, Bangkok, Thailand
}

\begin{abstract}
The debate in the field of Corporate Social Responsibility (CSR) in achieving Sustainable Competitive Advantage (SCA) was ongoing from the beginning of the twenty first century. The role of stakeholders and CSR in achieving sustainable business has increased in recent years. The purpose of this qualitative study was to achieve deeper understanding about the CSR initiative that may contribute to achieve SCA for the company. A single case study with three unit of analysis was used to achieve a deeper understanding on how CSR in planned, aligned and implemented in the noodle companies in Nepal and how those initiative may contribute to the company in the form of SCA and to community in the form of societal development.

The stakeholder theory was used as theoretical framework with semi structured interview as data collection method. For the data collection purpose, two groups of stakeholders were interviewed. The first group was internal stakeholders including managerial level employees and second group consisted of external stakeholders including suppliers, customers, local community members and environmental activist. The findings of the study clearly indicated that, the strategic approach to CSR contributes to company in the form of SCA and helps in fulfilling the expectations of the local communities. The findings indicated that, stakeholder management is a key tool in today's business environment and strategic CSR initiatives contributes in sustainable business and mutual cooperation between company and stakeholders.
\end{abstract}

Keywords: Corporate Social Responsibility; Sustainable Competitive Advantage; Noodle Company; Stakeholder Management.

\section{Introduction}

The research in the field of corporate social responsibility (CSR) and sustainable competitive advantage (SCA) grown in numbers since the start of $21^{\text {st }}$ century among the researchers and professionals who are engaged in research field (Suthisak\& Williams, 2009). The business environment nowadays has changed in various aspects from the past. Doing business and being successful in the market is not that easy. There are many factors which might affect the current business environment like consumer buying behavior, consumer perception, political situation, new business law and many more. When we think of starting a business firm, we should keep in mind about various aspects of a business like environmental factor, social factor and other factors like the stakeholders. At the beginning of the

\section{Cite this article as:}

D.R. Pant and O. Piansoongnern (2017) Int. J. Soc. Sc. Manage. Vol. 4, Issue-4: 275-283. DOI: 10.3126/ijssm.v4i3.17940

$1 *$ Corresponding author

Dinesh Raj Pant,

School of Management, Shinawatra University, Bangkok, Thailand

Email: dinesspant@gmail.com

Peer reviewed under authority of IJSSM

(C) 2017 International Journal of Social Sciences and Management

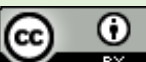

This is an open access article \& it is licensed under a Creative Commons Attribution 4.0 International License (https://creativecommons.org/licenses/by/4.0/ 
twenty first century, the concept of stakeholder started to develop to overcome the business challenges and from there the concept of CSR was developed (Katavic, 2014). Adding CSR and stakeholders in the corporate strategy helped the corporate leaders to bring the stakeholders to talk for the smooth operation of the business (Maxfield, 2008).

European Union (2011) defined CSR as voluntary integration of social and environmental initiatives into corporate strategies and practices as well as corporation's interaction with stakeholder such as shareholders/investors, employees, customers, suppliers, local community, and advocates who protect environment. Similarly, strategic CSR is defined as a responsible activity that helps corporate leaders to implement value-creating strategies (Mcwilliams \& Siegal, 2011). Due to global financial crisis and innovation of business technology, it is must that the corporate house should review their strategy to face and overcome the challenges. Integrating CSR initiatives (i.e., honest dialogue with all stakeholders, preserving the natural environment, prospering with the community, creating a safe, healthy and fair workplace, and acting ethically and building trust) into the agenda of the corporate strategy helped corporate leaders to earn a place in discussion central to business operations (Maxfield, 2008)

The term Sustainable Competitive Advantage (SCA) means to sustain or make their competitive advantage long lasting. Application of CSR initiatives could be expected in the strategic framework if it helps in SCA (Martinuzzi et al., 2010) and If the idea of how CSR initiatives impact the SCA could be identified then it could be beneficial to the corporate leaders to get information on considering the positive impact of CSR activities into corporate strategy and core business (Filho et al., 2010). Katavic (2014) agrees that, CSR has very high contribution in sustaining the competitive advantage and CSR has brought positive impact for the selected companies he researched. In order to achieve a deeper understanding on how CSR initiatives are planned, designed and implemented in the noodle industry of Nepal and how these initiatives may contribute community in the form of sustainable development and corporation in the form of SCA, this study was based on the stakeholder theory.

\section{Literature Review}

\section{Corporate Social Responsibility (CSR)}

The research and study in the field of CSR has been immense in present context. Penny (2001) and Dahlsurd (2008) further defined CSR as a set of management practice by the company to minimize the negative impact of its operation in society and maximize the positive impact (Dahlsrud, 2008). In recent past there has been huge increase in the interest of managers and CEOs regarding CSR activities and they are more aware of carrying out the CSR activities (Katavic , 2014). Business has become more pervasive and powerful over the years and there are expectations that the firms should engage in the CSR activities (Smith, 2003). The practice of CSR has been formed since last sixty years from leading European and US companies. At that time, the leading U.S and European companies came to understanding that they have to unite different elements of corporate policies related to the relationship of the company with the environment and to develop a single integrated approach to interact with societies (Madrakhimova, 2013).The starting point of concept of CSR can be traced out way back in 1953 when Bowen (1953) publish his book called "Social Responsibilities of the Businessman". That was the first book, which explained about social responsibility by a businessman and hence can be called as first step in concept of CSR (Katavic, 2014).

According to the scholars from past, CSR is a responsibility of a business that society has towards the organization at a given point in time. From the past, CSR was perceived as just a philanthropic work from the company and other organizations. The change in time and way of doing business has brought change in context of CSR as well. According to the modern scholars, CSR is a corporate strategy that focuses towards the stakeholders which ultimately help the company in the long run. A survey of 500 firms was carried out in Esrock\&Leichey (1999), and it showed that among $82 \%$ of the companies that it surveyed found to be engaged in at least one CSR activities. Furthermore, a survey of 1000 CEOs that was carried out by Jericho Communication in 2002 founded that more than $50 \%$ of the CEOs of selected firms believe that the CSR work is carried due to other reason except economical, legal and ethical responsibilities. Likewise, rests of the selected firms were engaged in CSR activities due to economical, legal and ethical responsibilities (Smith, 2003).

\section{Integration of CSR in Company's strategy}

Integrating corporate social responsibility in strategic framework help companies to gain competitive advantage, improve the financial position somehow and also create sustainable competitive advantage (Gomez et al, 2010). Patrizia (2014) further added that, the company should design socially responsible strategy that helps in gaining the intangible asset and that helps in sustaining of business and good image among the customers and other stakeholder. When CSR is integrated with the business strategy, it can crete competative differentation, permission to enter new markets and favourable positioning in the talent wars(McElhaney, 2010).

\section{Shareholder and Stakeholder Approach}

Shareholder Theory was first introduced by Friedman (1970) in an article in New York Times. According to Friedman (1970), the only social responsibility of the business is to use resource to increase the profit by staying 
within rule of game or rule of business. The main idea behind this theory by Friedman is that, the managers should focus on maximizing shareholder's profit and interest in the way that is permitted by the law or social values. Friedman (1970) further pointed out that, managers and executives are appointed and hired by the shareholders or owner of the company and shareholders own or spend money in business for only one purpose and that is profit. If business has to spend the money to the society then that will be like stealing because the profit is rightfully belongs to the shareholder of the company.

Stakeholder theory was firstly defined by Freeman (1984) in the book Strategic Management a stakeholder approach. Freeman (1984) describes stakeholders as any group or individual who can affect or is affected by the achievement of organization's objectives. Miles (2006) states that, organization itself should consider it as a group of stakeholder and the purpose of the organization should be to manage their interest, needs and viewpoint. Jeff (2003) believes that, managers have duty to both internal stakeholder and individuals and constituencies that contribute either voluntary or involuntary to the wealth creating capacity and a ctivities and who are therefore its potential beneficiaries or risk bearers. According to the stakeholder theory, managers are agents of all stakeholder and they have two responsibilities. The first one is to ensure that the ethical right of no stakeholder is violated and another one is to balance the legitimate interest of the stakeholder while making the decision (Jeff, 2003).

According to Ayton (2014), the new era in CSR has encouraged taking interest in stakeholders while in decision-making process instead of focusing only on profit maximization of shareholders. Bhattacharya et al. (2009) speculated, those CSR activities, which provide functional benefit to satisfy the important stakeholder value will impose the quality and strengthen the company shareholder relationship. Cocacola (2015) are highly committed towards the stakeholders and engaging stakeholder has played as a core mechanism for business and sustainability. Coca Cola have been using different mechanism for stakeholder engagement in the company by regular talks and other similar programs. There are different groups of stakeholders like community, customers, suppliers, and natural environment activists and have different ways of addressing the problems and dealing (Cocacola, 2015).

\section{Stakeholder Management and Sustainable Competitive Advantage (SCA)}

$\mathrm{Wu}$ (2010) argued that, there are two ways by which stakeholder management can influence the source of competitive advantage: Co-operative potential and potential threats of stakeholder. Strategies should be used to maximize the co-operative potential and minimize the threats so that it could help in value creation. Wu (2010) further found that, Stakeholder management helps to maximize the firm's resource capacity and ultimately it impact on sustainable competitive advantage. Herman (2016) explains that, it is very hard to sustain in the business for long without stakeholder management. Sustainable stakeholder management should be focused more to be in winning side by doing it efficiently and effectively (Herman, 2016).

\section{Relationship between CSR and SCA}

Making strategic decision about the CSR can be a major source of competitive advantage (Maduenoet al, 2016). The empirical study founded that; companies that are involved in the CSR initiatives have enhanced the company's reputation and improve the customers' satisfaction, which ultimately helps in creating SCA. The empirical study regarding sustainable competitive advantage found that manager's attitude and their entrepreneurial skills also play major role in stakeholder management which ultimately impacts the sustainability of competitive advantage. The fact can be supported by the finding of $\mathrm{Wu}$ (2013) that, to acchieve sustainable competative advantage firms shoul not only focus in strengthening their resource advantage capacity but also need to use innovative and entreprenual approaches for maintaining good stakeholder relation.

\section{Corporate Social Responsibility in Nepal}

The history of giving practice to the society is from past (Shah, 2012). According to the belief of Hindus and Buddhist, the main theme is Mokshya or Nirvana which can be achieving from good philanthropic work and the influence of religious belief and culture in philanthropic work is high(Dahal, 2001). The first process of social work can be traced out from the way back when there was "Arya Samaj" and at that time Madhav Raj Joshi with the help of "Swami Dayananda" generated awareness against the cruelty being imposed in the name of religion (Chand, 2000).During $9^{\text {th }}$ century, Sankhadhar Sakhwa, a wealthy trader, belonging to Newar ethnic community of Kathmandu cleared all debts of people of Kathmandu and freed them from debt and started new era called Nepal Sambat which is still practiced by Newar community of Nepal (Sharma, 1952).

According to Shah (2012), in Nepal Company has no good understanding of the fair concept of social responsibility and management of the company is more focused on maximizing profit and less engaged in social interest. The previous research in the field of CSR in Nepal shows that the concept of CSR in Nepal among corporate leaders and managers is now changing due to global education, research, training and education. The business these days is not only related with the profit maximization of the shareholders but also responsible to do something for the stakeholders. According to Adhikari (2012) though there is change in practicing the CSR but still both government and 
employers in Nepal are not serious in implementing the labor laws and the corporation has now understood that only by donating to the needy one when there is demand will not help them for the long term. The World Bank (2014) showed that, agriculture has key role of promoting the economy and reducing the poverty. Hence, many of the firms and company are attracted towards the agriculture sector and they have been carrying out the work of enhancing the agriculture by adopting the new technology, training to the farmers, providing loans in low rates for farming etc.

\section{Theoretical Framework}

Stakeholder concepts was adopted as the theoretical framework ( Aaltonen et al, 2008; Freeman, 1984; Jamali, 2008; Minoja, 2012; Rhenman\& Stymne,1965; Tse, 2011) for the purposed study to explore how the CSR initiatives integrated into the strategy and framework of the noodle companies in Nepal contribute to corporate SCA. During the mid 1980s, stakeholder theory began to gain attention with Freeman (1984) work that encouraged the leaders of the MNCs to consider new external stakeholders (i.e. local community \& environment) beyond shareholders, customers, employees, \& suppliers (Katavic, 2014).

Freeman (1994) argued that, stakeholder theory begins with the assumption that creating values are necessary and it is the part of business. This statement from Freeman (1994) suggests that, creating values and sharing with primary stakeholders by corporate leaders bring stakeholder together. The following assumption was explained in two main questions (Freeman, 1994). The first question was, what is the purpose of the corporation? This question challenges corporate leaders to identify and bring primary stakeholders together. Second, what responsibility do corporate leaders have to stakeholders (Freeman, 1994). This question challenges corporate leaders to explain how corporation- stakeholders can be build by organizing the business operations and to deliver the corporation's purpose (Katavic ,2014).Stakeholder theory suggested that without satisfying the needs of other stakeholders, maximizing shareholders value cannot be met (Jamali, 2008).

\section{Research Methodology}

A single case study was used as the qualitative method for the research. Single case study is the study of a particular group, individual or a unit as suggested by Yin (2004) and usuful in exploring a particular subject. The reason of selecting a single case was to explore more about CSR and SCA in noodle industry of Nepal. According to the research of Katavic (2014), qualitative case study with interview would be very useful to find out linkage between CSR and SCA.

A case study method seems very helpful to investigate about CSR and SCA as per the previous research Gomez et al.
(2010) and Katavic (2014). For the purpose of the study two sets of questionnaires for the interview of both the groups' i.e. corporate and external stakeholders were designed. Interview is the part of this qualitative research. Three method of interview i.e. in-person, telephone and email was used for interview. Along with the primary data the secondary data from the previous research, company's CSR report and other article related with the noodle industry of Nepal were also analyzed. The total number of questions for internal stakeholder was 42 and for external stakeholder were 17. There were total 9 study participants for the internal stakeholders and 18 study participants for the external stakeholders.

\section{Data Analysis}

Two types of data collection methods were used for analysis of data. Primary data was analyzed with the help of Thematic Analysis and secondary data was analyzed with the help of Content Analysis. Steps in data analysis for primary \& secondary data is shown in Fig. 1.

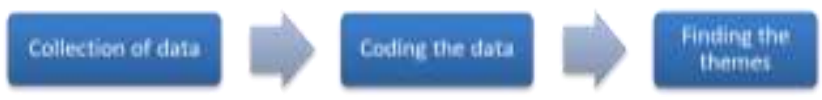

Fig. 1: Steps in Data Analysis for Primary \& Secondary Data

For primary data i.e. interview transcripts, all the transcripts were collected and entered in computer separately. The question wise responses of each respondent were compiled and after all the interview transcripts were entered the second steps was to analyze each responses that were given by the respondents. After preparing the tables, the responses concerning each question were analyzed for the coding. The main purpose of using coding method is to reduce the collected data (Yin , 2009). As suggested by (Katavic, 2014) at the time of analyzing the answers, the main, unique and different themes or findings were entered in the table.

After the completion of the tabulation work, each and every table was analyzed carefully for the purpose of coding. The process of reducing the data i.e. coding was done by finding the common responses from the participants. The analysis is based on frequency of responses. The common and unique idea and expression were then categorized into different heading according to the research questions and research objectives. After finishing the coding work the next step was to find the unique theme from the coded materials. All the responses coded under the different code were analyzed one by one and after analyzing the entire coded interview data themes were identified.

Similarly, secondary data were collected and entered into the computer separately according to the selected companies. More emphasis was given to the CSR and Internet reports regarding CSR and sustainability. From the secondary data, all the necessary information like total 
spending of companies in CSR activities, types of CSR activities, sales report, and sales growth were analyzed using content analysis method. The finding of the secondary data then combined with the primary data to support the findings.

\section{Result and Discussion}

\section{Profiles of the study Participants}

The findings from analysis of primary and secondary data yielded many themes. The findings are based on the analysis of emerged themes from collective response of internal and external stakeholders and empirical evidence showing the impact of CSR on SCA (Table $1 \& 2$ ).

\section{Linking CSR initiative with strategic plan is important}

The outcome of the interviews with the responded showed slightly different approach. $6(66.66 \%)$ out of 9 managers responded that, the CSR initiatives are linked with the company's strategic plan. Even though there were mix responses but it resulted in one single theme that, it is important to practice CSR in company's strategic plan. While $66.66 \%$ of respondents agreed the importance of the CSR in strategic plan, 3(33.33\%) of however reported that, they have not practiced the CSR as company's strategic plan yet.

According to one of the respondents "In our strategic plan itself we have specifically allocated certain percentage for the situations like - flood, earthquake. Likewise, certain percentage of the budget set aside for the community welfare activities near the factory location."(Ratna Dev Thapa, Senior Supervisor of Himalayan Snacks).

Table 1: Summary of data collection for internal stakeholder

\begin{tabular}{|l|l|l|}
\hline Chaudhary Group & Himalayan Snacks Pvt Ltd & Himshree Foods Pvt Ltd \\
\hline Location- Kathmandu & Location- Kathmandu & Location- Pokhara \\
\hline 3 Respondents & 3 Respondents & 3 Respondents \\
\hline 3 respondents interviewed by email & 2 respondents interviewed by email & \\
\hline 3 male respondents & 1 respondent interviewed by telephone & 3 respondents interviewed in- person \\
\hline & 2 male respondents & 3 male respondents \\
\hline
\end{tabular}

Table 2: Summary of data collection for external stakeholder

\begin{tabular}{|l|l|l|}
\hline $\begin{array}{l}\text { Represented Company- } \\
\text { Chaudhary Group }\end{array}$ & $\begin{array}{l}\text { Represented Company- Himalayan } \\
\text { Snacks Pvt Ltd }\end{array}$ & $\begin{array}{l}\text { Represented Company- Himshree } \\
\text { Foods Pvt Ltd }\end{array}$ \\
\hline $\begin{array}{l}\text { Email- 1 , In- person - 4, } \\
\text { Telephone- 1 }\end{array}$ & 6 respondents & 6 respondents \\
\hline Environmental Activist- 1 & Environmental Activist- 1 & Email- 2, In- Person- 3, Telephone- 1 \\
\hline Customer/Community Member-1 & Customer/Community Member-1 & Customer/Community Member-2 \\
\hline $\begin{array}{l}\text { Employee/ Community Member- } \\
1\end{array}$ & Employee/ Community Member- 1 & Employee/ Community Member- 1 \\
\hline Customer- 1 & & \\
\hline Educational Activist- 1 & Customer -2 & Customer -1 \\
\hline Supplier - 1 & Supplier - 1 & \\
\hline
\end{tabular}


Another response revealed that "We have good relation with the stakeholder which helps us to sustain in the competitive market." (Krishna Khatri. HR assistant manager of Chaudhary Group).

The secondary source of data also supports the finding of the interview data that, companies have put the CSR initiatives in the strategic plan and have separate department for the CSR. The secondary source of data also supports that the effectiveness of the CSR programs as a strategic plan. The two companies Chaudhary Group (2015) and Himalayan Snacks (2015) have good practice of CSR and they have separate CSR department. The reports also shows the work being carried out and the impact it has done to the society and stakeholders. The CSR initiatives has been able to build good brand image and loyality. The company engaging in CSR initiatives have been able to get good support from the stakeholders and which can be seen by the sales and market share of the company.

The findings is well supported by the emperical study of Luo \& Bhattacharya (2006) that, strategicall planned CSR has positive effect to the company's market value and they supports that the company may gain sustainable competative advantage because of it if they invest in CSR.The findings of this theme according to the respondents, proper planning and implementation of CSR has helped in generating valuable benefit to both company and stakeholders and hence it has supported in the competitive advantage.

\section{Good CSR practices are important for gaining SCA}

The outcome of the theme suggested that, 6(66.66\%) of managers perceive that the role of CSR in gaining SCA is very high. They further stated that, doing CSR or helping the society supports the competitive advantage like product differentiation, brand loyalty.

According to one respondent, "When we came here to start the business, it was so difficult. The infrastructure was poor. It was hard to convince the local people. Maximum political pressure was there at that period. We were struggling. Gradually, when we implemented our CSR activities like supporting the primary education in the community, distributing necessities during the fire, supporting to make the environment clean, community people trusted us. They supported and it became easy to work. Similarly we provided education support to the needy people, which helped to fulfill our national goal of education for all." (BishalSapkota, Human Resource Assistant manager of Himalayan Snacks)

However, out of 9 respondents $3(33.33 \%)$ stated that, they have not practiced the CSR as a business strategy, so the impact of CSR in SCA is difficult to measure. However, they were of the opinion that making CSR as a part of strategy could help the SCA and it would be easy to measure the impact as well. Overall the mix approaches suggested that, CSR is very helpful for competitive advantage and sustainability of the competitive advantage.

\section{Stakeholder management as a backbone in sustainability of the business:}

According to the respondents, out of the total 9, all agreed on stakeholders as a backbone of the business. The combined data of the respondents yields that, companies nowadays are more positive towards CSR and stakeholders management. The theory of stakeholder management by Freeman (1984) seems to be very helpful for the business in present context.

According to one respondents, "I think CSR is a backbone of any company. CSR is a way to show society that we are doing business ethically and we are supporting the society rater than just only focusing the profit. We follow stakeholder theory in our business i.e. customers are very important. Due to globalization of business and education, the perception of the business has changed in recent past and has engaged more towards the society and other CSR related activities." (Kewal Jung Swar, Finance manager of Chaudhary Group)

Another response was, "CSR is not just a means to giving to society. It is a strategy to do business and do business ethically. Stakeholder Management is very important in today's global business environment. Without the support from stakeholder and without supporting stakeholder and $i$ don't think any business in today's changing and competitive environment can sustain." (Rojhan Tiwari, Finance manager of Himalayan Snacks)

The responses can clarify that, the way of doing business has changed from the past and also the thinking of the people has changed. Respondents agree that, due to expanding education, trainings and new dynamics in learning has changed the way of thinking of the people and they have become more aware about the activities of the business. The failure of the shareholder theory can be reviewed in the literature review part and managers nowadays wants to focus more on stakeholder so that they can get good result for the company alongside protecting stakeholder interest.

According to the respondents, mutual cooperation with stakeholders is very necessary for the company and stakeholders for benefit of both the parties. In addition to that, meeting the societal expectations by CSR initiatives is very important for the better relations. Most of the respondents argued that, the societal and environmental work like supporting the community members, help in education and health sector, creating more job opportunities, supporting the local suppliers of raw materials and preserving the natural environment can be the way to get good supports from the stakeholders. 


\section{Meeting Societal Expectation for gaining SCA}

The combined data from managers and external stakeholder yielded the theme that meeting societal expectation helps in achieving sustainable competitive advantage by the help and support from the stakeholders. According to the data of internal stakeholder $66.66 \%$ stated that companies has been able to meet the societal expectations which have helped them to sustain for the longer period of time. The data of internal stakeholders can be well supported by the data from external stakeholder, $77.77 \%$ responded that the selected companies have been able to meet their expectations. They supported their argument by stating that, due to political instability in the country the government has not been able to carry out the development and other societal work but the companies have helped in education, building roads in the rural areas, helped in health sector and during the time of natural calamities.

\section{Effect of CSR in customer loyalty for SCA}

According to the data collection from internal stakeholder it was found that, all the respondents $(100 \%)$ has agreed that CSR helps in customer loyalty by building trust. The findings from the data of external stakeholder moderately support internal stakeholders. Sixty-six percentages of respondents from external stakeholders are positive towards the company's product and have trust on the company. In case of Nepal, the preference of customer towards the particular brand is very high. All the three studied companies have their own customers and they are able to maintain the customer loyalty. The finding is well supported by the empirical study of Shrestha (2012) that, all the three studied companies for this research have been able to retain top three position in Nepal according to customer loyalty.

According to the responses, $66.66 \%$ reveals that CSR has helped in building brand image and customer loyalty and that has helped in sustainable competitive advantage. The responses from both the groups of studied participants revealed that, they have been able to retain their customers and the effect of CSR like healthy product, good natural environment and help in education is very high. Thus, two company Chaudhary Group (2015) and Himalayan Snack's (2015) CSR has helped to gain the customers and that has able to make positive effect in sustainable competitive advantage.

\section{CSR has helped the SCA in the form of brand equity and company image}

The role of brand equity and company image in competitive advantage can be seen from the data collection. Both primary and secondary data supports the fact that CSR has a role to play for gaining sustainable competitive advantage. According to the data collection, 66.66 percentages of managers agrees that, CSR has helped the company in building brand equity and company image which has impacted somehow on sustainable competitive advantage.
The data of managers is supported by the external stakeholder and 66.66 percentages of the respondents are liable towards the company which helps in building company image and brand equity.

The findings also revealed that, sharing values with the customers helps to build their loyalties and ultimately the brand equity which has helped in gaining the sustainable competitive advantage.

\section{Summary and Conclusion}

The main aim of this study was to invistage the practice of the CSR and deeper understanding of the impact of CSR in the SCA of a company using stakeholder theory as framework.The finding suggested that, the concept of the CSR has changed in the present context. The perception of the managers as well as stakeholders has lead the company to engage in the societal and environmental activities. Furthermore, strategic approcah to the CSR have positive impact on the company and stakehlolder.

The findings also suggested that, the impact of following stakeholder theory in buisness has helped both company and stakeholders and the managers are psoitive about maintaining good company and stakeholder relation. Likewise, there will be positive support from the stakeholder towards the company who are involve in societal and environmental activities. Furthermore, the concept of SCA and CSR has grown in present context and more emphasis should be given in the academic filed to the learners regarding this. Moreover to the corporate leaders in food and beverage industry, the perception of people has changed and they want quality product.

The research also founded that the strategic approcah to CSR has helped the sampled companies to gain support from the stakeholders as well as betterment in their financial performance which has impacted the sustainable competative advantage. The findings also suggested that, the companies in Nepal are positive towards stakeholder management.

\section{References}

Aaltonen K, Jaakko K and Tuomas O (2008) Stakeholder salience in global projects. International Journal of Project Management 26: 509-516.

Adhikari D (2012) Status of corporate social responsibility in selected Nepalese companies. Corporate Governance: The international journal of business in society 12: 642655.

Ayton M (2014) What is the difference between a shareholder and a stakeholder? Retrieved from Investopedia: http://www.investopedia.com/ask/answers/08/differencebetween-a-shareholder-and-a-stakeholder.asp

Bank W (2014) World Bank Reports. Retrieved from World Bank: http://econ.worldbank.org/WBSITE/EXTERNAL/EXTD EC/EXTRESEARCH/EXTWDRS/EXTNWDR2013/0,„c 
ontentMDK:23330018 pagePK:8258258 piPK:8258412 $\sim$ theSitePK:8258025,00.html

Bhattacharya C, Korschun D and Sen S (2009) Strengthening Stakeholder Strengthening stakeholder- company Relationships through Mutually Beneficial Corporate Social Responsibility Initiatives. Journal of Business Ethic 2: $257-272$.

Chand D (2000) Understanding voluntary action in Nepal. Development NGOs facing the 21st Century, Perspectives from South Asia, Kathmandu. Institute of Human Development 65-73.

Cocacola (2015) Coca Cola Journey. From Coca Cola Journey: http://www.coca-colacompany.com/stories/stakeholderengagement

Dahal D (2001) Civil Society of Nepal - Opening the Ground for Questions. Kathmandu: Centre for Development and Governance.

Dahlsrud A (2008) How corporate social responsibility is defined: an analysis of 37 definitions. Corporate Social Responsibility and Environment Management 15: 1-13.

European C (2011). Communication from the commission to the European parliament, the council, the European economic and social committee and the committee of the regions $\mathrm{A}$ renewed EU strategy 2011-14 for Corporate Social Responsibility. Retrieved from http://eurlex.europa.eu/legalcontent/en/ALL/?uri=CELEX:52011DC0681

Filho J, Wanderley L, Gómez C and Farache F (2010) Strategic Corporate Social Responsibility Management for Competitive Advantage. Brazalian Administration Review 7: 294-309.

Freeman R (1984) Strategic management: A stakeholder's approach. Pitman, Boston, MA.

Freeman R (1994) The politics of stakeholder theory: Some future directions. Business Ethics Quarterly 4: 409-404.

Friedman M (1970) The social responsibility of business is to increase its profits. The NewYork Times Magazine, p. 32. Retrieved from http://www.nytimes.com/

Gomez GF, Manzanares D and Skerlavaj M (2010) The integration of corporate social responsibility into the strategy of technology-intensive firms: a case study. Zb. Rad. Ekon. Fak. Rij. 28: 9-34.

Herman P (2016) From TNS: http://www.tnsinfratest.com/presse/pdf/autorenbeitraege/hermann_stake holder_management.pdf

Jamali D (2008) A stakeholder approach to corporate social responsibility. Journal of Business Ethics 82: 213-231.

Jeff H (2003) The Shareholders vs. Stakeholders Debate. Retrieved from MIT Sloan, Management Review: http://sloanreview.mit.edu/article/the-shareholders-vsstakeholders-debate/
Katavic I (2014) Corporate Social Responsibility and Sustainable Competitive Advantage: A Case Study of the Cement Industry. Published by ProQuest LLC.

Kloss A (2010) The integration of expatriates: How expatriates living in Denmark define integration. From http://studenttheses.cbs.dk/bitstream/handle/10417/1025/ andrea_kloss.pdf?sequence

Kothari C (2004) Research Methodology: Methods and Techniques, Second Revised Edition. New Delhi: New Age International Publisher.

Madrakhimova F (2013) History of Development of Corporate Social Responsibility. Journal of Business and Economics 4: 509-520. From http://www.academicstar.us/UploadFile/Picture/20146/201461410571606.pdf

Martinuzzi A, Gisch-Boie S and Wiman A (2010) Does corporate responsibility pay of? Exploring the links between CSR and competitiveness in Europe's industrial sectors. Research Institute for Managing Sustainability. From http://www.sustainability.eu/

Maxfield S (2008) Reconciling corporate citizenship and competitive strategy: Insights from economic theory. Journal of Business Ethics 80: 367-377.

McElhaney K (2010) A Strategic Approach to Corporate Social Responsibility. Retrieved from University of California, Berkeley, Haas School of Business: http://claridenglobal.com/programs/CGArticle_CSRLead ership.pdf

Mcwilliams A and Siegal D (2011). Creating and capturing value: Strategic corporate social responsibility, resource-based theory, and sustainable competitive advantage. Journal of Management 37(5): 1480-1495.

Miles AF (2006) Stakeholders: Theory \& Practice. Onford University Press.

Minoja M (2012) Stakeholder management theory, firm strategy, and ambidexterity. Journal of Business Ethics 109: 67-82.

Patrizia G (2014) CSR integration into the corporate strategy. Cross-Cultural Management Journal 16: 331-338.

Rhenman E and Stymne B (1965) Corporate management in a changing world. Aldus/Bonniers, Stockholm.

Shah KK (2012) Corporate Social Responsibility in Nepal. Academic Voices 2: 33-37.

Sharma BC (1952) An outline of the history of Nepal. Varanasi.

Smith N (2003) Corporate Social Responsibility: Weather of How? California Management Review.

Tse T (2011) Shareholder and stakeholder theory: After the financial crisis. Qualitative Research in Financial Markets 3: $51-63$.

Wu M (2010) The Search of Competitive Advantage: A Stakeholder Management Prospective. New Zealand. 
Wu M (2013) Towards a Stakeholder Perspective on Competitive Advantage. International Journal of Business and Management 8: 20-29.

Yin R (2004) Cosmos Corporation. Retrieved from Cosmos Corporation.:

http://www.cosmoscorp.com/Docs/AERAdraft.pdf
Yin R (2009) Case study research: Design and methods (4th ed.). Thousand Oaks CA, Sage Publications, Inc.

Yin RK (1984) Case study research: Design and methods. Newbury Park, CA. Retrieved from https://www.ischool.utexas.edu/ ssoy/usesusers/1391d1b. htm 